\title{
Health Seeking Behaviour among Elderly People of Bharatpur Municipality of Chitwan District, Nepal
}

\author{
Rojina Baral, ${ }^{1}$ Pramila Sapkota ${ }^{2}$ \\ ${ }^{1}$ Department of Nursing, College of Medical Sciences, Bharatpur, Chitwan, Nepal, ${ }^{2}$ Beacher Hall Care Home-BUPA, \\ Reading, United Kingdom.
}

\begin{abstract}
Background: Individuals have different opinion regarding willingness to seek help from health care services. Some go readily for treatment, others only when in great pain and in advance state of ill health. This is especially true for people with advance age who have to face many physiological changes which act as a barrier to seek immediate help in health care setting. Thus, a study was conducted to analyse the health seeking behaviour among elderly. Materials and Methods: A cross-sectional analytical study was conducted among 104 elderly aged 60 years and above. Non- probability convenience sampling technique was used to collect the data. Data was collected by interviewing the elderly at their residence. The data gathered was analyzed using both descriptive and inferential statistics in SPSS software. Results: Assessment of the health status of elderly people revealed that, majority of the participant's $86.5 \%$ were suffering from chronic health problem, among them $37.8 \%$ suffered from hypertension $11.1 \%$ suffered from diabetic mellitus. Whereas, assessment of the practice of health seeking behaviour among elderly stated that all the participant's $100 \%$ were seeking help for health problem in which $83.7 \%$ seek help from modern medication and still $16.3 \%$ seek help from alternative medication. Also, the health seeking behavior was found to be statistically significant with health problem $(p=0.002)$, ethnicity $(0.007)$ and religion $(p=0.007)$ respectively. Conclusions: Elderly are aware of seeking help from the health care center, but still elderly believe in alternative medication rather than modern medication which may be an alarming truth in the health care setting.
\end{abstract}

Keywords: alternative medication; elderly; health seeking behaviour; modern medication.

\section{INTRODUCTION}

As a result of declining fertility, mortality as well as improved public health interventions, population ageing has been a world-wide phenomenon. People today are living longer and generally healthier lives. ${ }^{1}$ Health seeking behavior is the act of making a decision to seek or not to seek health care from qualified medical personnel when not feeling well. ${ }^{2}$ Factor affecting health seeking behavior among elderly is found to be significantly associated with types of health facilities, distance of nearest health facility, ignorance of disease due to old age, poverty, poor attitudes of health worker, lengthy treatment process, trust on god for healing if ill, living alone and lack of someone to take them to hospitals. ${ }^{3}$ Old age and ill-health are perceived to be inseparable entities. Seeking health care from a formally qualified doctor is avoided due to high costs. Flexibility of health care providers in receiving payment is a crucial deciding factor of whether or not to seek treatment, and even the type treatment sought. ${ }^{4}$ Attribution of ill health to ageing, low economic status and negative attitude of health workers towards the care of the elderly are some of the factors associated with delay in seeking health care. ${ }^{3}$ Some factors that determine health behaviour may be physical, socio-economic, cultural or political. ${ }^{5}$ Indeed, the utilization of a health care system may depend on educational levels, economic factors, cultural beliefs and practices. Other factors include environmental conditions, sociodemographic factors, and knowledge about the facilities, gender issues, political environment, and the health care system itself. 6,7 Thus, this study aims to assess the health status and pattern of health seeking behaviour among elderly people.

\section{MATERIALS AND METHODS}

A cross-sectional analytical study was conducted among 104 elderly aged over 60 years in Krishnapur7, Bharatpur, Chitwan to assess the health status and pattern of health seeking behaviour. Ethical approval

Correspondence: Rojina Baral, Department of Nursing, College of Medical Sciences, Bharatpur, Chitwan, Nepal. Email: rojina.baral@gmail.com. Phone: +977-9845817996. DOI: 10.3126/jcmsn.v14i3.21178. Article received: 2018-06-26. Article accepted: 2018-08-10. 
Baral et al. Health Seeking Behaviour among Elderly People of Bharatpur Municipality..

was received from the Institutional Review Board of College of Medical Sciences. and permission from VDC of Krishnapur-7 was obtained. Written consent was signed from all study participants. Nonprobability convenience sampling technique was used to collect the data. Elderly who were unable to communicate and had psychiatric illness were excluded from the study. Data was collected by direct face to face interview at their residence. Kuppuswamy Socio-economic Scale was used as a part to assess the socio-demographic data and structured questionnaire regarding the present health status and their health seeking behaviour was used as a tool of the study. Data was entered in Excel and SPSS version 20 was used for statistical analysis. Descriptive statistics was used to analyze sociodemographic factors while chi square test was used to find out the association between sociodemographic characteristics and health seeking behaviour.

\section{RESULTS}

Among total of 104 participants, nearly $50 \%$ of elderly belong to age group $60-69$ and $53.8 \%$ were male. Also $70.2 \%$ were married and $28.8 \%$ were widowed. Almost 90 percent of participant were Brahmins and followed Hinduism. Considering the educational status, $64.4 \%$ were literate, all were employed in the past and $67.3 \%$ were still employed. Majority of the participants live in a joint family and only $48.1 \%$ are aware of the availability of health facilities (Table 1). Table 2 shows that majority $86.5 \%$ participant's had some kind of health problems among which hypertension (36.7\%) was more prevalent. Health seeking behaviour among elderly has been depicted in Figure 1. The certain parameters like ethnicity, religion and health problem was significantly associated with the health

\begin{tabular}{|lr|}
\hline \multicolumn{2}{|l|}{ Table 2. Health Problems of Elderly $(\mathbf{n = 1 0 4})}$. \\
\hline Variables & $\mathbf{n}(\%)$ \\
Health problem of participant & $90(86.5 \%)$ \\
No & $14(13.5 \%)$ \\
Type of health problem & \\
Hypertension & $34(37.8 \%)$ \\
Diabetes mellitus & $10(11.1 \%)$ \\
Uterine problem & $1(1.1 \%)$ \\
Asthma & $12(13.3 \%)$ \\
Others (Gastritis, joint pain, Piles and & $33(36.7 \%)$ \\
Hearing problem) & \\
\hline
\end{tabular}

Table 1. Socio-demographic characteristics.

\begin{tabular}{|c|c|c|}
\hline $\begin{array}{l}\text { Socio- } \\
\text { demographic } \\
\text { characteristics }\end{array}$ & Category & n (\%) \\
\hline Age of participant & $\begin{array}{l}60-69 \\
70-79 \\
\geq 80\end{array}$ & $\begin{array}{l}46(44.2) \\
40(38.5) \\
18(17.3)\end{array}$ \\
\hline Gender & $\begin{array}{l}\text { Male } \\
\text { Female }\end{array}$ & $\begin{array}{l}56(53.8) \\
48(46.2)\end{array}$ \\
\hline Marital status & $\begin{array}{l}\text { Married } \\
\text { Widowed }\end{array}$ & $\begin{array}{l}73(70.2) \\
31(28.8)\end{array}$ \\
\hline Caste-ethnicity & $\begin{array}{l}\text { Brahmin/chettri } \\
\text { Janajati }\end{array}$ & $\begin{array}{l}89(85.6) \\
15(14.4)\end{array}$ \\
\hline Religion & $\begin{array}{l}\text { Hindu } \\
\text { Bouddha }\end{array}$ & $\begin{array}{l}89(85.6) \\
15(14.4)\end{array}$ \\
\hline Working status & $\begin{array}{l}\text { Yes } \\
\text { No }\end{array}$ & $\begin{array}{l}70(67.3) \\
34(32.7)\end{array}$ \\
\hline $\begin{array}{l}\text { Present occupa- } \\
\text { tion }\end{array}$ & $\begin{array}{l}\text { Profession } \\
\text { Semi-profession } \\
\text { Clerical,shop-owner,farmer } \\
\text { Skilled worker } \\
\text { Semi-skilled worker } \\
\text { Unskilled worker }\end{array}$ & $\begin{array}{c}2(2.9) \\
3(4.3) \\
14(20.0) \\
7(10.0) \\
6(8.6) \\
38(54.3)\end{array}$ \\
\hline $\begin{array}{l}\text { Did you work in } \\
\text { the past time }\end{array}$ & Yes & $104(100)$ \\
\hline $\begin{array}{l}\text { Your previous } \\
\text { occupation }\end{array}$ & $\begin{array}{l}\text { Profession } \\
\text { Semi-profession } \\
\text { Clerical,shop-owner,farmer } \\
\text { Skilled worker } \\
\text { Semi-skilled worker } \\
\text { Unskilled worker }\end{array}$ & $\begin{array}{c}7(6.7) \\
3(2.9) \\
49(47.1) 11 \\
\quad(10.6) \\
19(18.3) \\
15(14.4)\end{array}$ \\
\hline $\begin{array}{l}\text { Family income per } \\
\text { month (Nrs) }\end{array}$ & $\begin{array}{l}\geq 45751 \\
22851-45750 \\
17151-22850 \\
11451-17150 \\
6851-11450 \\
2301-6850 \\
\leq 2300\end{array}$ & $\begin{array}{c}8(7.7) \\
27(26.0) \\
15(14.4) \\
17(16.3) \\
18(17.3) \\
7(6.7) \\
12(11.5)\end{array}$ \\
\hline \multicolumn{3}{|l|}{ Educational status } \\
\hline Literate & $\begin{array}{l}\text { Profession or honours } \\
\text { Graduate or post graduate } \\
\text { Intermediate/Post high school } \\
\text { diploma } \\
\text { High school certificate } \\
\text { Middle school certificate } \\
\text { Primary school certificate }\end{array}$ & $\begin{array}{c}1(1.0) \\
4(3.8) \\
10(9.6) \\
6(5.8) \\
3(2.9) \\
43(41.3)\end{array}$ \\
\hline Illiterate & & $37(35.6)$ \\
\hline
\end{tabular}

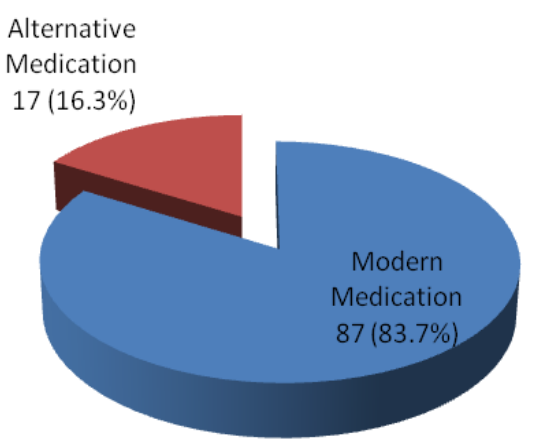

Figure 1. Health seeking behaviour among elderly. 
Baral et al. Health Seeking Behaviour among Elderly People of Bharatpur Municipality..

seeking behaviours while type of family, staying with family, availability of health facility and distance from house were also analyzed which was not statistically significant $(\mathrm{p}<0.05)$ (Table 3$)$.

\begin{tabular}{|c|c|c|c|}
\hline Variable & $\begin{array}{c}\text { Modern } \\
\text { medication }\end{array}$ & $\begin{array}{l}\text { Alternative } \\
\text { medication }\end{array}$ & $\begin{array}{c}P \\
\text { value }\end{array}$ \\
\hline $\begin{array}{l}\text { Ethnicity } \\
\text { Brahmin/chettri } \\
\text { Janajati }\end{array}$ & $\begin{array}{c}78 \\
9\end{array}$ & $\begin{array}{c}11 \\
6\end{array}$ & $0.007 *$ \\
\hline $\begin{array}{l}\text { Religion } \\
\text { Hindu } \\
\text { Bouddha }\end{array}$ & $\begin{array}{c}78 \\
9\end{array}$ & $\begin{array}{l}11 \\
6\end{array}$ & $0.007 *$ \\
\hline $\begin{array}{l}\text { Health problem } \\
\text { Hypertension } \\
\text { Diabetic mellitus } \\
\text { Uterine problems } \\
\text { Asthma }\end{array}$ & $\begin{array}{r}34 \\
8 \\
1 \\
9\end{array}$ & $\begin{array}{l}0 \\
2 \\
0 \\
3\end{array}$ & $0.002^{*}$ \\
\hline
\end{tabular}

\section{DISCUSSION}

Health seeking behaviour is an individualized phenomenon. There are numerous factors that can affect this behaviour, especially among aged ones. In the assessment of the study, majority of the participants belong to age group of $60-69$, more than half of the participants were male and two third were married. Almost 90 percent of participant were Brahmins and followed Hinduism, which is regarded as the highest religion followed in Nepal. ${ }^{8}$ Regarding the literacy and employment status, $64.4 \%$ were literate, all were employed in the past and $67.3 \%$ were still employed. Increase in literacy and being employed changes the perspective of elderly in securing the health care needs and improves the decision making in seeking help from the qualified medical personnel. Majority of the participants live in a joint family and only $48.1 \%$ are aware of the availability of health facilities.
Majority of the participants $86.5 \%$ had some kind of health problems among them $37.8 \%$ suffered from hypertension, $11.1 \%$ from Diabetes Mellitus and $36.7 \%$ from other problems such as Piles, hearing problems, joint pain and gastritis. The result shows this finding is consistent with the study conducted by Adhikari et al., ${ }^{3}$ and Sharma et al., ${ }^{9}$ which showed that large number of participants were suffering from at least one health problem and reported illness among elderly were hypertension, diabetes mellitus, arthritis, joint pain and hearing problem.

The study showed that nearly two third of elderly $(83.7 \%)$ seek help from modern medication but still one third (16.3\%) elderly seek help from alternative medication. Adherence to alternative medication may be due to the lack of care taker, poverty, superstitious belief etc. Study conducted in Pakistan, ${ }^{10}$ Dhulikhel, ${ }^{11}$ Fikkal and Pashupatinagar ${ }^{12}$ and Kenya ${ }^{13}$ showed that elderly are still seeking help in health related to issues to alternative medicine and traditional healer plays a salient role in health care of elderly. Significant association between health seeking behaviour and ethnicity $(p=0.007)$, religion $(p=0.007)$ and health problem $(\mathrm{p}=0.002)$ is sought in this study. This finding can be correlated with the similar study done in Dharan ${ }^{3}$ which revealed that ethnicity was significantly associated with health seeking behaviour.

\section{CONCLUSIONS}

Elderly have a positive behaviour towards seeking help in regards to the health care. Multiple morbidities were evident among elderly, and modern medication was of a greatest choice. Improved perspective towards health, easy accessibility, awareness regarding the disease may contribute for the willingness of seeking help for the health care needs.

\section{REFERENCES}

1. United Nations, Department of Economic and Social Affairs, Population Division (2015). World Population Ageing. [Full Text]

2. Lambert, SD; Loiselle, CG (2007). "Health information seeking behavior". Qual Health Res. 17 (8): 1006-1019 [Pubmed]

3. Adhikari, D. \& Rijal, D. (2010).Factors Affecting Health Seeking Behavior of Senior Citizen of Dharan. Journal of Nobel Medical College 3 (1).50-57. [Link]

4. Biswas, P., Kabir, Z. N., Nilsson, J. \& Zaman, S. (2006). Dynamics of Health Care Seeking
Behavior of Elderly People in Rural Bangladesh. InternationalJournal of Ageing and Later Life, 1(1). 69-89 [Link]

5. Kroeger A. Anthropological and socio-medical health care research in developing countries. Soc Sci Med. 1983;17:147-161. [Pubmed]

6. Ogunlesi TA, Olanrewaju DM. Sociodemographic Factors and Appropriate Health Care-seeking Behavior for Childhood Illnesses. J Trop Pediatr. 2010;56(6):379-385. [Pubmed]

7. Katung PY. Socio-economic factors responsible for poor utilization of primary health care services in rural community in Nigeria. Niger $\mathbf{J}$ 
Baral et al. Health Seeking Behaviour among Elderly People of Bharatpur Municipality..

Med. 2001;10:28-29. [Pubmed]

8. National Population and Housing Census. National Planning Commission Secretariat, Central Bureau of Statistics, Government of Nepal, Vol 1, 2011. [Link]

9. Sharma, D., Parashar, A., \& Mazta, S. R., (2013). Morbidity Pattern and Healthseeking Behavior of Aged Population residing in Shimla Hills of North India. Journal of Family Medicine and Primary Care. [Pubmed]

10. Shaikh,B.T., and Hatcher,J.(2004). Health seeking behavior and health service utilization in Pakistan: challenging the policy maker on Pakistan. Journal of Public Health Vol-27, No.1, pp. 49-54 . [Pubmed]

11. Sanjel, S., Mudbhari, N., Risal, A \& Khanal,
K. (2012). Utilization of Health Services and their Determinants among Elderly Population in Dhulikhel. Kathmandu University Medical Journal. 10 (1).34-39. [Nepjol]

12. Bhattarai,S., Parajuli,S.B., Rayamajhi,R.B., Paudel, I.S., Jha,(2013). Health Seeking Behavior and Utilization of Health Care Services in the Village Development Committees of Ilam District of Nepal. Journal of College of Medical Sciences-Nepal, Vol-11, No 2, Apr-Jun 015. [Link]

13. Abubakar, A., Baar, A.V., Fischer, R., Bomu, G., Gona, J.K., Newton, C.R. (2013). SocioCultural Determinants of Health-Seeking Behavior on the Kenyan Coast: A Qualitative Study. [PloS]

Citation: Baral R, Sapkota P. Health Seeking Behaviour among Elderly People of Bharatpur Municipality of Chitwan District, Nepal. JCMS Nepal. 2018;14(3):150-3 